\title{
Floating Market Tourism Area: Sustainable Tourism Management Strategy
}

\author{
Deasy Arisanty ${ }^{1 *}$ Eva Alviawati ${ }^{1}$ Faisal Arif Setiawan ${ }^{1}$ Sidharta Adyatma ${ }^{1}$ \\ Akhmad Munaya Rahman ${ }^{1}$ \\ ${ }^{1}$ Department of Geography Education, Lambung Mangkurat University, Brigjend H. Hasan Basry, South Kalimantan \\ 70123, Indonesia \\ ${ }^{*}$ Corresponding author. E-mail: deasyarisanty@ulm.ac.id
}

\begin{abstract}
Floating market tourism area Lok Baintan is a unique tourist area in Indonesia. However, the existence of this floating market is still not well managed, so it is less developed. The purpose of this study is to analyze the potential, weaknesses, opportunities, and threats in the management of the Lok Baintan tourism area and determine the sustainable management strategy of the Lok Baintan Floating Market tourism area. Respondents in this study are traders who trade in Lok Baintan Floating Market by 6 people, manager of the Lok Baintan tourism area and at the same time the village head of Lok Baintan by 1 person, and the Tourism Office of South Kalimantan Province by 1 person. SWOT analysis is used to determine the strategy in the management of this tourist area. The results showed that the strategy in the management of this tourism area is to complete tourism facilities, tourism product innovation, enhancing the quality of tourism actors, regeneration of tourism actors, and financial support for enhancing tourism product and facility innovations. The synergy between local government policies and the community as tourism actors is needed to create tourism activities sustainable.
\end{abstract}

Keywords: Strategy, management, sustainable, tourism

\section{INTRODUCTION}

Indonesia is a country that is very rich in culture and nature. This wealth makes Indonesia a country that has very diverse tourist destinations. The Indonesian government has set various tourism destinations as development priorities [1]. The tourism sector is a source of foreign exchange for the country [2],[3].

Tourism activities have a positive impact on economic growth in Indonesia [4]. So that the tourism sector becomes more developed, various types of tourism development strategies are needed. Various kinds of promotions have been carried out by the Indonesian government to attract tourists to come to Indonesia [5]. Another strategy is the allocation of resources for the development of the tourism industry, specifically by supporting infrastructure development and promoting tourism in Indonesia through more advertising, removing visa restrictions, and implementing discount programs for tourism groups [6]. The use of technology and information is also a strategy to increase the role of the tourism sector in economic growth in Indonesia, such as e-tourism [7].

The tourism sector in Indonesia has become a source of community livelihood [8]. Tourism development is an effective strategy for poverty reduction and sustainable livelihoods [9]. The tourism sector has provided a better quality of life for the community [10]. Tourism activities help maintain local populations, create new jobs, and contribute to the socio-economic progress of disadvantaged areas [11].

Lok Baintan Floating Market is a reliable tourist destination in the province of South Kalimantan. This tourist destination makes the river and the traditions of people selling on the river a tourist attraction. The community sells agricultural products, fisheries, and handicrafts using traditional boats or jukung. Tourists also buy merchandise using motorized boats called kelotok [12],[13].

Although these tourism activities have become the main tourist attractions in South Kalimantan Province, the welfare of traders as tourism actors is still very low. Their income is only around 20,000-50,000 IDR / day. The income is not able to meet the needs of people's lives. This is due to the management of tourist areas which are still very limited, even though tourism activities in this area depend on tourist attractions carried out by traders [14]. Poor management of tourist areas causes various problems, so strategies are needed to overcome these problems. The strategy is determined by looking at the potentials, weaknesses, opportunities, and challenges contained in the region. Based on the background, the purpose of this study is to analyze the potential, weaknesses, opportunities, and threats in the management of the Lok Baintan tourism area and determine the management strategy of the Lok Baintan Floating Market tourism area that is sustainable. 


\section{LITERATURE REVIEW}

\subsection{Development Strategy for Sustainable Areas}

Tourism is a complex socio-economic phenomenon based on the evolving needs of modern society for recreation. Tourism is one of the fastest-growing sectors in the world and is seen as a desirable investment option [15]. As a complex economic activity, tourism has a lot to do with other economic activities and has an impact on the economy, on society, and the environment [16].

The principles and practices of sustainable tourism need to be applied to achieve national development goals [17]. Sustainable tourism activities have the principle of openness, mobility, and ease of travel [18]. Community participation, tourism infrastructure, and tourist visits have a positive and significant influence on the performance of the tourism industry and the quality of people's lives [10]. The structure of competitiveness in the tourism industry consists of five dimensions: risk management and adaptive environmental strategies, innovation, and product development, planning for sustainable development, networks, and public awareness, and education for sustainability [19].

Strategies in developing tourist areas include community empowerment and empowerment for managers to manage tourist destinations to be better in the future and be able to provide services and guarantee satisfaction for all tourists [20]. Strengthening the competitiveness and attractiveness of tourism products, considering new world experiences, while relying on innovation itself is an important tourism management strategy [11]. A collaborative tourism capacity building approach (TCCB) is a strategy to train indigenous entrepreneurs and local staff based on dialogue and knowledge integration, build on pre-existing capabilities, and encourage innovation through joint creation and use of creative tools [21]. Innovation can increase competitiveness and profitability [22].

Tourism development strategies need to consider indicators of strategic planning and implementation, monitoring, and evaluation [23]. Optimal tourism planning decisions are decisions that consider the needs of tourists and residents [24]. The tourism industry development strategy contributes to moving barriers that hinder the development of the tourism industry [25]. Sustainable industrial development recommends a process to unite various interests, to contemplate, identify, and prioritize various tourism potentials, to help people become more energetic and resilient [26].

\section{MATERIALS AND METHODS}

This research is qualitative. This research was conducted at Lok Baintan Floating Market. This Tourism Area is a major tourist destination in South Kalimantan Province with a distinctive culture and cannot be found in other regions in Indonesia [13]. Data obtained through field observations and depth interviews from January 2019 to June 2019. Respondents in this study were traders who traded at Lok Baintan Floating Market by 6 people, managers of Lok Baintan tourism area, and at the same time Lok village chiefs of Baintan, and 2 people, and South Kalimantan Province Tourism Office as many as 2 people. Interviews were conducted using Indonesian, then recorded using a tape recorder and recorded using stationery. Questions are open, and respondents answer questions more freely. The list of questions raised in this study is in Table 1 .

Table 1 List of Questions in Research

\begin{tabular}{|l|l|}
\hline \multicolumn{1}{|c|}{ Questions } & \multicolumn{1}{c|}{ Rationale } \\
\hline respondent identity & Socio-demographic \\
\hline What is the potential that exists in the Lok Baintan Floating Market? & The Potential of Lok Baintan Tourism Objects \\
\hline $\begin{array}{l}\text { Are the Weaknesses in developing Tourism Areas in the Lok Baintan } \\
\text { Floating Market }\end{array}$ & The Weaknesses of Lok Baintan Attractions \\
\hline What are the opportunities in developing Lok Baintan attractions? & Lok Baintan Tourism Object Opportunities \\
\hline $\begin{array}{l}\text { What are the challenges faced by tourism actors and local governments in } \\
\text { developing Lok Baintan tourism objects? }\end{array}$ & Lok Baintan Tourism Object Challenges \\
\hline $\begin{array}{l}\text { What is the strategy undertaken by the Department of Tourism and the } \\
\text { community in managing the Lok Baintan Floating Market tourist area? }\end{array}$ & Government Strategy \\
\hline
\end{tabular}

To obtain data validation in this study, a crosscheck was made between the results of observations, interviews, and documentation. Data analysis uses triangulation techniques (data reduction, data display, and data verification). Interview results are reduced according to the focus of the study. The results from the reduction are then described to get the results of the study. The results of the data obtained in the field are also verified with secondary data obtained from literature reviews and information from relevant agencies. SWOT analysis can be used to identify internal and external factors including strengths, weaknesses, opportunities, and threats [27]. Determination of management strategies needed to improve tourism in the study site by using a SWOT analysis with due regard to these internal and external factors [28]. SWOT analysis can be used to develop sustainable tourism strategies [29].

\section{RESULTS AND DISCUSSION \\ 4.1 Potential in the Management of the Lok Baintan Tourism Object the Lok BaintanTourism}

Floating Market Area is a mainstay tourist area in South Kalimantan. Tourists in this tourism area are traders who 
trade on the river using traditional boats called jukung. The goods sold in the floating market are agricultural products such as fruits and vegetables, local fish in rivers and swamps around the floating market area, and handicrafts. All tools and materials used in these floating market activities are traditional.

Trading on the river is a tradition of the tribe community Banjar which is a river community. Even though it is not used as a tourist area, it will still sell on the river. The river has always been the pulse of the economy of the tribe community Banjar. The uniqueness of trading on the river is then used as a unique tourist attraction because it is not found in other regions in Indonesia. The community expressed their pride and desire to continue to preserve the trading culture by utilizing the river. This makes the floating market sustainable until now, although the modern market is also growing rapidly in the city of Banjarmasin.

Local government support is also very large for this floating market area. Various promotions such as through tourism events continue to be carried out by local governments, such as the following interview with Respondent 1: One of the major events prepared by the Department of Tourism is the 1000 jukung event at the Lok Baintan floating market. Through this promotion, it is expected to attract tourists to come to the floating market. Another local government support is through the formation of a tourism awareness group (Pokdarwis), as follows: an interview with Respondent 2 follows: another form of development is the formation of a tourism awareness group in Lok Baintan with the hope that with this group the community will be fostered how to manage tourist activities.

Facility support is also carried out by local governments, such as the construction of piers in collaboration with the private sector. The local government through the village fund also built road facilities so that to get to the tourist attraction not only through the river but through land transportation, as quoted in the interview with Respondent 5 below: In terms of development in the floating market tourism objects, road improvements were made to get to the floating market. Lok Baintan, so that tourists can not only use river transportation, they can also reach the Lok Baintan floating market by using land transportation. This is an additional income for the surrounding community because it can open a parking lot around a tourist attraction. Electric facilities and parking locations are also available at this place. The existence of this facility supports Lok Baintan floating market tourism activities.

Sustainable development is increasingly becoming a priority issue in the development of tourism in the modern world. To make tourism sustainable, programs are needed by local governments around developing sustainable tourism, identifying problem areas, and proposing solutions [30]. The government must also commit to improve infrastructure and complete the necessary facilities. Coordination between related agencies must be improved so that development in the tourism sector can mutually support one region to another and not become competition [1].

\subsection{Weaknesses in Management of Baintan Lok Tourism Objects}

Promotional activities carried out by local governments are still annual or biennial events due to limited funds, as expressed by Respondent 1 below: 1000 jukung activities as promotions cannot be carried out once a year due to budget cuts. Activities in the form of tourist awareness group training also cannot be carried out routinely. Tourism awareness groups that have been formed have not actively developed, as follows: Respondent 3 interview excerpts: Pokdarwis was established in 2014, the chairman of this village. While this role does not exist because there is no guidance from the district, there are activities that are not very visible. Constraints experienced by village officials who cannot focus on tourism development are limited funds and the lack of human resources that make it possible to foster tourism-aware groups.

Sustainable tourism should have a greater emphasis on tourism products that lead to greater industry and environmental sustainability [15]. Cooperation between local governments, businesspeople, NGOs, the community makes many investors and tourists come to a tourist area [31]. Limited funds in developing this floating market tourism area, require investors from the private sector and businesspeople so that funds do not only come from local governments. These funds can be used to develop human resources and innovate tourism products.

This tourism area is also lacking in terms of tourism facilities. There is a desire from the local government to develop this tourist area, such as the construction of a floating shop, but has not yet been implemented. Lodging facilities for tourists also do not yet exist. During this time tourists stay in the city of Banjarmasin, while the location of this tourist attraction is about $10 \mathrm{~km}$ from the city of Banjarmasin. People at the tourist sites do not get other benefits from these attractions besides the merchandise sold in the floating market. The motorized boat that is used by tourists is not from this attraction but is managed by a hotel in the city of Banjarmasin and works with motorized boat owners in the city. Facilities in the form of restaurants, souvenir shops, information centers or tourist guide offices, and security posts as a standard that must exist in tourist areas are also not yet available in this area. Funding constraints become a problem. This tourism object is not well managed and is not a priority, so tourism facilities are lacking.

\subsection{Opportunities that exist in the management of Baintan Lok Tourism Objects}

The local government has a desire for this tourism object to develop properly. The local government also wishes to continue training to develop human resources, especially their skills in making innovative products from agricultural or fishery products into high-value products, and various handicrafts that are characteristic of this region. Local governments also wish to form small and medium enterprises (SMEs) in the region such as interviews with Respondents 3: The form of activities is in the form of 
special training for people in tourist areas in the form of screen-printing clothes and key chains, the results of which can be marketed in tourist attractions for tourists.

Local governments also wish to foster tourism awareness groups, such as the following interview with Respondent 1 respondent: People who are members of Pokdarwis will manage their tourist objects without relying again on the government. For this development alone the funds that are seconded to support this activity are 15,000,000 / group for funding to bring in experts to foster them. Although these funds are not routine due to lack of funds, they can be a trigger for the development of tourism awareness groups. Tourism conscious people want to participate in tourism activities accompanied by support from the local government.

Awareness to preserve this tourist area is also an opportunity for the preservation of this attraction, as the following interview excerpted with Respondent 3: A sense of pride and a desire to preserve the culture of trading in rivers, and rivers are considered as sources of livelihood make this floating market continue to survive. Trading activities are considered by the community as a source of income while preserving river culture. This trading activity has opened business opportunities for villagers who are dominated by old age and have low education.

Population perceptions in the development of a tourist area can be different so managers must consider development opportunities and adopt appropriate strategies at various stages of development [32]. The positive perception of the population has a positive effect on their support and participation in tourism development. Support and participation of residents in tourism planning can sustain tourism development [33], [34]. Communities in the Lok Baintan tourist area strongly support the existence of this floating market to be used as a tourist area due to a sense of community pride in river culture. This is a strength and opportunity for an area to become a sustainable tourism area.

\subsection{Challenges that exist in the Management of the Lok Baintan Tourism Area}

Low income from traders due to tourism products sold in this market is very limited to agricultural products, fisheries, and the limited types of crafts. Tourists, especially national or international tourists will have difficulty when buying goods in the form of fruits, vegetables, and fish to take them to a hotel or inn, so in general, tourists only take pictures of the trading without buying. Only domestic tourists who come from the area around the floating market buy merchandise. This makes their income only around IDR 20,000-50,000 per day. The innovation of tourism products such as products from agricultural products, fisheries, and handicraft products has not yet been carried out to the full. The desire of the community is the existence of training in processing fruits or fish so that the products increase their income. However, local governments have not prioritized product innovation. The focus of the local government is still on the implementation of tourism promotion, not on the innovation of tourism products and tourist facilities. The different desires of the people and local government policies make a challenge in the management of this tourist area.

Sustainable tourism development places a harmonious relationship between the community, product innovation, and other components [31]. The involvement and collaboration of stakeholders make tourism activities sustainable [35]. The disharmony between the wishes of the regional government and the people in the Lok Baintan Floating Market Area requires a policy from the regional government to harmonize the desires of the two parties in determining priorities in developing the tourist area.

Traders in the floating market are also dominated by the elderly and have low education. Not found young people who trade in this tourist area. This is certainly a threat to the sustainability of this floating market. Most young people consider low income and less promising to make the low interest of the younger generation to continue trading in this market as their parents do.

\subsection{Lok Baintan Floating Market Tourism Management Strategies}

Various strategies in managing the Lok Baintan Floating Market area by considering the strengths, weaknesses, opportunities, and threats contained in this tourism area are as follows:

a. Adding tourism facilities that do not yet exist in the Lok Baintan floating market area such as lodging, restaurants, shops souvenir, proper toilets, information centers, or tourist guide offices, security posts.

b. Improving the quality of human resources (HR) by improving the skills of tour operators (traders) and tourism awareness groups in terms of innovation in tourism products.

c. Increase river culture events aimed at preserving and promoting river culture by involving tourism actors in these activities, which are carried out routinely every year.

d. Promotion of tourism not only through events but through social media and local government websites.

e. Increasing the role of young people in tourism activities to preserve the Lok Baintan Floating Market tourist area Baintan by packaging these attractions becomes more interesting.

f. Increasing the source of funds to improve the quality of tourism and tourism facilities in collaboration with the private sector and businesspeople.

g. Increased tourism product innovation and product competitiveness to increase the income of tourism actors (traders).

h. Establish tourism policies that align the desires of local governments and communities, by increasing the role of the community in planning the development of tourism areas. 
Improving tourism infrastructure and facilities is the right strategy to make the tourism area more developed. Also, cooperation between the government and the management of tourism zones in promoting tourism zones through festivals is a strategy for the development of tourism zones [36]. Community participation in tourism activities that are effective and meaningful in planning Tourism areas become a strategy in the development of community-based tourism areas [37]. The image of tourism destinations, infrastructure development, training, and workforce education, quality management, and sustainable management is needed by public and private policy stakeholders who prepare for the future of tourism [38]. The Lok Baintan Floating Market also needs a lot of improvement to make the tourism area sustainable, especially the synergy between the local government and tourism actors in making decisions related to tourism activities. The existing potential is used as capital for tourism areas and the existing problems are corrected so that this area can still be preserved as a tourist area with a distinctive culture in Indonesia.

\section{CONCLUSION}

Tourism activities have provided opportunities for tourism actors to earn income. Even so, it turns out that income has not been able to improve the welfare of the community. Tourism facilities, tourism product innovation, regeneration of tourism actors, and limited funds in the tourist area are also problems in tourism activities. A management strategy is needed so that tourism activities become sustainable. This research recommends the involvement of the tourism community in making decisions related to tourism activities and the synergy of policies that can make the tourism area sustainable.

\section{REFERENCES}

[1] Cholik, M. A., \& SE, M. (2017). The development of tourism industry in Indonesia: Current problems and challenges. European Journal of Research and Reflection in Management Sciences Vol, 5(1).

[2] Antara, M., \& Sumarniasih, M. S. (2017). Role of tourism in economy of Bali and Indonesia. Journal of Tourism and Hospitality Management, 5(2), 34-44.

[3] Ollivaud, P., \& Haxton, P. (2019). Making the most of tourism in Indonesia to promote sustainable regional development.

[4] Widodo, W., \& Sugiyanto, F. X. (2019). Tourism and Economic Growth Nexus In Indonesia: The Dynamic Panel Data Approach. Regional Science Inquiry, 11(2), 8391.

[5] Rudenko, S., \& Tedjakusuma, A. P. (2018, March). " Wonderful Indonesia" country marketing campaign-how visible Indonesia as a tourism destination for Europeans. In 15th
International Symposium on Management (INSYMA 2018). Atlantis Press.

[6] Primayesa, E., Widodo, W., \& Sugiyanto, F. X. (2019). The Tourism-Led Growth Hypothesis in Indonesia. E-review of Tourism Research, 17(1).

[7] Jonathan, C. J., \& Tarigan, R. (2016). The Effects of e-tourism to the development of tourism sector in Indonesia. CommIT (Communication and Information Technology) Journal, 10(2), 59-62.

[8] King, C. (2017). Tourism in Raja Ampat: New Chances and Challenges.

[9] Lasso, A., \& Dahles, H. (2018). Are tourism livelihoods sustainable? Tourism development and economic transformation on Komodo Island, Indonesia. Asia Pacific Journal of Tourism Research, 23(5), 473-485.

[10] Wardana, A. G. O. P., Utama, M. S., Yasa, I. N. M., \& Budiasa, I. G. S. (2018). Effect of Community Participation, Tourism Infrastructure, Tourist Visit to The Tourism Industry Performance and The Quality Living Community in Bali Indonesia. International Journal of Sustainability, Education, and Global Creative Economic (IJSEGCE), 1(1), 79-86.

[11] Mihic, S., Mihajlovic, M., \& Dasic, D. (2018, June). European Funds as Stimulative Support In Developing The Marketing Strategy For Tourism Of Vojvodina. In Proceedings of International Academic Conferences (No. 6408679). International Institute of Social and Economic Sciences.

[12] Arisanty, D., E. Normelani, H. P. N. Putro and M. Z. A. Anis. 2017. The role of women in Lok Baintan Floating Market, South Kalimantan: implication for tourism development. Journal of Indonesian Tourism and Development Studies 5(3), 169-174.

[13] Arisanty, D., E. Normelani, H. P. N. Putro and M. Z. A. Anis. 2018. Local products of Lok Baintan Floating Market, South Kalimantan Province. IOP Conf. Series: Earth and Environmental Science $145 . \quad$ DOI: 10.1088/1755-1315/145/1/012067.

[14] Arisanty, D., E. Normelani, H. P. N. Putro and M. Z. A. Anis. 2020. Women Traders Livelihoods in Tourism Area of Lok Baintan Floating Market. Journal of Indonesian Tourism and Development Studies, 8(1),25-32.

[15] Nicolaides, A. (2020). Sustainable Ethical Tourism (SET) and Rural Community Involvement.

[16] Coccossis, H. (2016). Sustainable development and tourism: Opportunities and threats to cultural heritage from tourism. In Cultural tourism and sustainable local development (pp. 65-74). Routledge. 
[17] Rutty, M., \& Richardson, R. B. (2019). Tourism Research in Cuba: Gaps in Knowledge and Challenges for Sustainable Tourism. Sustainability, 11(12), 3340.

[18] Ruiz-Ballesteros, E., \& Cáceres-Feria, R. (2016). Community-building and amenity migration in community-based tourism development. An approach from southwest Spain. Tourism Management, 54, 513-523.

[19] Armenski, T., Dwyer, L., \& Pavluković, V. (2018). Destination competitiveness: Public and private sector tourism management in Serbia. Journal of travel research, 57(3), 384398.

[20] Isdarmanto, I. (2016). Analysis Strategy of Tourism Development at Kalibiru Kulon Progo As A Leading Tourist Attraction in Yogyakarta Special Region. Kepariwisataan: Jurnal Ilmiah, 10(3).

[21] Espeso-Molinero, P. (2017). Collaborative capacity building as a resilience strategy for tourism development in indigenous Mexico. In Tourism, Resilience and Sustainability (pp. 184-201). Routledge.

[22] Ab Rahman, Z. N., Ismail, N., \& Rajiani, I. (2018). Challenges for managing nontechnological innovation: a case from Malaysian public sector. Polish Journal of Management Studies, 17

[23] Nowacki, M., Kowalczyk-Anioł, J., Królikowska, K., Pstrocka-Rak, M., \& Awedyk, M. (2018). Strategic planning for sustainable tourism development in Poland. International Journal of Sustainable Development \& World Ecology, 25(6), 562-567

[24] Din, K. H. (2018). Dialogue with the hosts: An educational strategy towards sustainable tourism. In Tourism in South-East Asia (pp. 327-336). Routledge.

[25] Li, H. (2018). Research on Development Strategy of Tourism Industry in the Southern Sichuan Economic Zone. Journal of Service Science and Management, 11(01), 83.

[26] Pedersen, A. (2016). Frameworks for tourism as a development strategy. In Reframing sustainable tourism (pp. 47-63). Springer, Dordrecht.

[27] Munandar, A. (2017). The Business Strategy and Management of Tourism Development for the Growth of Tourist Visits. International Journal of Economic Perspectives, 11(1).

[28] Reihanian, A., Mahmood, N. Z. B., Kahrom, E., \& Hin, T. W. (2012). Sustainable tourism development strategy by SWOT analysis: Boujagh National Park, Iran.tourism management Perspectives, 4, 223-228.
[29] Sulistyadi, Y., Eddyono, F., \& Hasibuan, B. (2017). Model of sustainable tourism development strategy of the Thousand Islands Tourism Area-Jakarta. Journal of Economics, Management and Trade, 1-17.

[30] Kapera, I. (2018). Sustainable tourism development efforts by local governments in Poland. Sustainable cities and society, 40, 581588.

[31] Grytsiuk, M., Grytsiuk, P., \& Gryciuk, Y. (2017). Building a sustainable tourism development strategy in the Carpathian region of Ukraine. Zeszyty Naukowe. Organizacja $i$ Zarzadzanie/Politechnika Ślaska.

[32] Lee, T. H., \& Jan, F. H. (2019). Can communitybased tourism contribute to sustainable development? Evidence from residents' perceptions of the sustainability. Tourism Management, 70, 368-380.

[33] Rasoolimanesh, S. M., \& Jaafar, M. (2017). Sustainable tourism development and residents' perceptions in World Heritage Site destinations. Asia Pacific Journal of Tourism Research, 22(1), 34-48.

[34] Zhu, H., Liu, J., Wei, Z., Li, W., \& Wang, L. (2017). Residents' attitudes towards sustainable tourism development in a historical-cultural village: Influence of perceived impacts, sense of place and tourism development potential. Sustainability, 9(1), 61.

[35] Lee, T. H., \& Hsieh, H. P. (2016). Indicators of sustainable tourism: A case study from a Taiwan's wetland. Ecological Indicators, 67, 779-787.

[36] Oktavia, M., \& Heldayani, E. (2019, June). Development Strategy for the Special Interest of Sustainable Tourism Object of Palembang. In IOP Conference Series: Earth and Environmental Science (Vol. 286, No. 1, p. 012038). IOP Publishing.

[37] Porter, B. A., Orams, M. B., \& Lück, M. (2018). Sustainable entrepreneurship tourism: An alternative development approach for remote coastal communities where awareness of tourism is low. Tourism Planning \& Development, 15(2), 149-165.

[38] Andrades, L., \& Dimanche, F. (2017). Destination competitiveness and tourism development in Russia: Issues and challenges. Tourism management, 62, 360-376. 